\title{
Bromeliads production in greenhouses associated to different shading screens
}

\author{
Ester Holcman; Paulo Cesar Sentelhas \\ ESALQ, Depto. de Eng. de Biossistemas, C. Postal 9, 13418-900 Piracicaba-SP; eholcman@esalq.usp.br; pcsentel.esalq@usp.br
}

\begin{abstract}
Bromeliads production in greenhouses is highly influenced by microclimate, which affects plants growth and development. Based on that, this study aimed to evaluate the influence of shading screens of different colors on microclimatic variables and Aechmea fasciata bromeliad growth in a greenhouse covered by transparent low-density polyethylene. The experiment had five treatments, with screens of different colors, inside a plastic greenhouse: thermo-reflective (T1); control without screen (T2); red (T3); blue (T4); and black (T5) screens, all of them with $70 \%$ of shading. From the 60 plants arranged in each one of the treatments 24 were evaluated, which were obtained randomly. The statistical design was completely randomized for the biometric variables. An automatic micrometeorological station was installed in each treatment, recording temperature, relative humidity and solar radiation. The plant parameters evaluated weekly were plant diameter and height, leaf width and length, and number of leaves per plant. The rosette diameter and leaf length were the parameters that presented the highest differences among treatments, which was basically a function of changes in solar radiation caused by the shading screens. The red screen provided the best conditions for $A$. fasciata bromeliad production.
\end{abstract}

Keywords: Aechmea fasciata, plant growth, solar radiation, air temperature.

\section{RESUMO}

Produção de bromélias sob malhas de sombreamento em casa de vegetação

A produção de bromélias em ambiente protegido é altamente influenciada pelo microclima, o qual afeta tanto o desenvolvimento como o crescimento das plantas. O objetivo do presente trabalho foi avaliar a influência de malhas de sombreamento de diferentes cores nas variáveis microclimáticas e no crescimento da bromélia Aechmea fasciata em ambiente protegido coberto com polietileno de baixa densidade transparente. Os tratamentos foram compostos por diferentes malhas de sombreamento: termo-refletora (T1), testemunha sem malha (T2), vermelha (T3), azul (T4) e preta (T5), todas com $70 \%$ de sombreamento. Das 60 plantas dispostas em cada um dos tratamentos, foram avaliadas 24 delas obtidas aleatoriamente. $\mathrm{O}$ delineamento estatístico foi inteiramente casualizado para as variáveis biométricas. Um sistema automático de aquisição de dados micrometeorológicos foi instalado em cada tratamento, obtendo registros de temperatura do ar, umidade relativa do ar e radiação solar. As variáveis das plantas avaliadas foram altura e diâmetro da planta, largura e comprimento das folhas e número de folhas por planta. $\mathrm{O}$ diâmetro da roseta e o comprimento das folhas foram as variáveis que apresentaram as maiores diferenças entre os tratamentos, em função das alterações na radiação solar causadas pelas malhas de sombreamento. A malha vermelha promoveu as melhores condições para a produção da bromélia $A$. fasciata.

Palavras-chave: Aechmea fasciata, crescimento, radiação solar, temperatura do ar.

(Recebido para publicação em 5 de setembro de 2012; aceito em 8 de julho de 2013) (Received on September 5, 2012; accepted on July 8, 2013)

$\mathrm{B}$ romeliads are distributed across Tropical and Subtropical areas of Americas. South America is considered the center of great diversity. Nowadays, more than 3.200 bromeliads species are known, with $70 \%$ of the genus and more than $40 \%$ of the species occurring in Brazil (Grant \& Zijlstra, 1998), inhabiting all parts of the country, but having the Atlantic coast as the largest diversity center (Paula, 2001).

The different bromeliads genera require different light intensities to their full development. The optimal climatic conditions for each species of bromeliad are those predominant in the center of origin, which determine the degree of shading for them (Carvalho et al., 1998; Carvalho \& Rocha, 1999). Therefore, for growing bromeliads in a commercial scale is important that the environment could be adapted according to their climatic requirements.

The bromeliads are one of the main ornamental plants cultivated in greenhouses. Considering that microclimate inside greenhouses can be modified and controlled (Medeiros, 2002), suitable conditions for bromeliads growth can be generated and the shading screens have been used for this purpose. Thus, the knowledge of the actual solar radiation transmissivity of the cover materials is of crucial importance for a better production in greenhouses. This is possible only by applying the results from the field experiments which indicate how good shading can be for producing a given plant or crop. For Cermeño (1994), the sunshine is important for all plants' metabolic processes. Specific advantages can be obtained with the use of different shading screens, with special optical properties, which can modify the composition of the light spectrum that reaches the plants, improving the yield and quality of them (Oren-Shamir et al., 2001). Shading can result in a positive effect on the quality and homogeneity of production (Briassoulis et al., 2007), 
mainly in sunny and hot regions (AlHelal \& Abdel-Ghany, 2010). Because of their physical structure, shading screens promote a mixture of direct and diffuse radiation, which is issued by the photo-selective threads (Shahak, 2008). However, not all microclimatic changes are beneficial for plants (Sentelhas \& Santos, 1995). The plants cultivated in greenhouses normally suffer with heat excess along the summer season in tropical and sub-tropical regions, when the solar irradiance is very intense (Mashonjowa et al., 2010).

According to Oliveira (1995), the main problems associated to the use of greenhouses in tropical regions are caused by high air temperatures and relative humidity observed within these structures, causing physiological disturbs and favoring occurrence of diseases. Also, the lack of information about how to manage the greenhouse appropriately in relation to the macro and microclima is the cause of low crop yield and quality.

The bromeliads are one of the major ornamental plants cultivated in greenhouses, since they require very specific conditions to grow properly, combining temperature, relative humidity, light, nutrients and soil water availability, which vary among the different species (Went, 1940; Pittendrigh, 1948; Johansson, 1974; Grant \& Zijlstra, 1998).

In order to circumvent the difficulties faced by greenhouse growers in tropical regions, the use of colored shading screens is increasing around the world. These screens combine inside reduction of solar radiation with the stimulation of specific morphological and physiological reactions in plants, improving production efficiency and quality (Shahak, 2008). For Nomura et al. (2009), the colorful screens have the ability to change the solar radiation intensity and its spectrum, becoming an alternative to the use of plant regulators. Therefore, the use of different combinations of cover materials in greenhouse is a reality, especially for ornamental plants production. It has demanding studies for characterizing the physical environment and its influences on plants growth and development.
Based on that, the objective of this study was to evaluate the influence of shading screens of different colors on microclimatic parameters and on A. fasciata bromeliad growth in a greenhouse covered by transparent lowdensity polyethylene.

\section{MATERIAL AND METHODS}

The experiment was conducted from $11 / 04 / 2005$ to $30 / 06 / 2006$ in the experimental area of the Agricultural College "Luiz de Queiroz", University of São Paulo, in Piracicaba, São Paulo state, Brazil (2242'40'S, 47³7'30'W, altitude of $546 \mathrm{~m}$ ). In accordance with the Köppen classification, the climate of the region is Cwa, which means tropical humid with dry winter. The experiment was installed in a greenhouse with 17.5 $\mathrm{m}$ of length; $6.4 \mathrm{~m}$ of width; $3.5 \mathrm{~m}$ of height, being covered with a transparent low density polyethylene plastic film, 0.15-mm thick.

A. fasciata micropropagated plants used in the experiment were provided by "Bromélias Rio" company, with 33 weeks of age. In 11/04/2005, the bromeliads were transplanted to vases $\left(n^{\circ} 14\right)$, filled with commercial substrate, with the following composition: pine bark, peat, coal, fosmag (magnesium multiphosphate), FTE and limestone, manufactured by Terra do Paraíso ${ }^{\circledR}$. The fertilization was done with two different nutritive solutions (A and B). The fertirrigation was performed 3 times a week, manually. Two times with solution A (NPK 20-08-20 + magnesium sulfate), and once with the solution $\mathrm{B}$ (NPK 20-08-20 and calcium nitrate), both with electrical conductivity of 0.8 $\mu \mathrm{S}$. For each fertirrigation $70 \mathrm{~mL}$ of the nutritive solution was applied per vase, which changed along the cycle, in accordance to the development of the plant.

The bromeliad plants were divided in the following treatments inside the greenhouse: treatment 1 (T1) covered with thermo-reflective screen; treatment 2 (T2) was the control, not covered with shading screen; treatment 3 (T3) covered with red screen; treatment 4 (T4) covered with blue screen; and treatment 5 (T5) covered with black screen. All the screens, which represent the most used by growers, had $70 \%$ of shading and were installed at $1.0 \mathrm{~m}$ above of the plants. Each treatment was composed by 60 vases cultivated with one bromeliad plant per vase, organized in 6 lines and 10 columns, with dimensions of $3.0 \times 1.2 \mathrm{~m}$ and height of $1 \mathrm{~m}$. Measurements related to the $A$. fasciata bromeliads growth were made weekly on 24 samples per treatment, starting on $23 / 12 / 2005$. The experimental design for biometric characteristics (rosette diameter, plant height, leaf number per plant, leaf width and leaf length) was the samples completely randomized. The results were submitted to the analysis of variance and the averages were compared by the Tukey test, at $5 \%$ of probability, using the Software ASSISTAT ( 7.6 beta version).

The environmental physics analysis was done by micrometeorological measurements with automatic sensors. As the micrometeorological sensors were not available for the five treatments simultaneously, they were installed for the period of one week in each treatment, in a system of rotation. With such system, the micrometeorological measurements were done for five weeks in each treatment. The sensors were connected to a datalogger CR10x model (Campbell Sci.), which continuously recorded air temperature $(\mathrm{T})$ and relative humidity (RH), with a thermocouple psicrometer of forced ventilation. Moreover, a sensor was used for the measurement of incoming solar radiation $(\mathrm{Rg}$ - model CM3, Kipp \& Zonen) and another for net radiation ( $\mathrm{Rn}$ - NR-lite model, Kipp \& Zonen). For the measurement of photosynthetically active radiation (PAR), a Licor LI190SB-Quantum sensor (spectral band 400 to $700 \mathrm{~nm}$ ) was used. The micrometeorological data were collected from $27 / 12 / 05$ to $30 / 06 / 06$ and compared to weather data from an automatic weather station installed outside of the greenhouse, in order to detect the changes caused by the micro-environments. The relative differences between variables obtained inside and outside of the greenhouse were calculated for all treatments, determining the $\mathrm{Rg}$, PAR and $\mathrm{Rn}$ transmitted into each treatment. Also 
the percentages of PAR in the $\mathrm{Rg}$ in all the greenhouse treatments and outside were determined, as well as the differences between inside and outside air temperature $\left({ }^{\circ} \mathrm{C}\right)$, relative humidity $(\mathrm{RH})$, actual water vapor pressure (ea), and saturation water vapor pressure (es).

\section{RESULTS AND DISCUSSION}

Table 1 presents the percentage of the solar radiation that effectively achieved the plants inside the greenhouse for each treatment. The T2 (control treatment) presented the highest percentages, since it does not have the effect of the screens. In this treatment the values of transmissivity were, on average, of $56 \%$ for $\mathrm{Rg}$ and $43 \%$ for PAR. Among the other treatments, the T3 (red screen) presented the highest transmissivity values for $\operatorname{Rg}(27 \%)$ and PAR (12\%). Very similar results were found by Jeong et al. (2009), studying begonias cultivated in a greenhouse in the region of Columbus (Ohio, USA), obtaining $\mathrm{Rg}$ transmissivity around 24\% for screens of $80 \%$ of shading. The smallest transmissivity occurred in the T5 (black screen), followed by thermo-reflective (T1) and blue (T4) screens, as presented in Table 1.

The smaller PAR transmissivity observed in the black screen (T5), thermo-reflective screen (T1) and blue screen (T4) treatments was also obtained by Al-Helal \& Abdel-Ghany (2010), who concluded that the darker the screen color the greater is the capacity of the screen to absorb PAR. These values are similar to those obtained by Pandorfi (2006) who observed that PAR inside of a greenhouse covered with plastic and thermo-reflective screen was $20.6 \%$ in relation to outside conditions. LugassiBen-Hamo et al. (2010), studying the effect of the shading in Lisianthus caused by clear plastic screens installed inside greenhouse in the south region of Israel, observed solar radiation transmissivity between 12 to $33 \%$, which can be compared to the results presented in Table 1 for the treatments 1,3 and 4 .

Throughout the experiment, it was observed for the treatments with screen cover that red screen (T3) was the one

Table 1. Incoming solar radiation ( $\mathrm{Rg}, \%$ ), photosynthetically active radiation (PAR, \%), net radiation $(\mathrm{Rn}, \%)$ and $\mathrm{PAR} / \mathrm{Rg}$ proportion transmitted into each treatment, being: $\mathrm{T} 1=$ thermo-reflective screen; $\mathrm{T} 2=$ control; $\mathrm{T} 3=$ red screen; $\mathrm{T} 4=$ blue screen; and $\mathrm{T} 5=$ black screen (radiação solar incidente $(\mathrm{Rg}, \%)$, radiação fotossinteticamente ativa (RFA, \%) e saldo de radiação $(\mathrm{Sr}, \%)$ transmitidas ao interior de cada tratamento, sendo: $\mathrm{T} 1=$ malha termo-refletora; $\mathrm{T} 2=$ testemunha; $\mathrm{T} 3=$ malha vermelha; $\mathrm{T} 4=$ malha azul; $\mathrm{e}$ T5=malha preta). Piracicaba, ESALQ, 2006.

\begin{tabular}{lrcrrr}
\hline Variables & T1 & T2 & T3 & T4 & T5 \\
\hline Rg & 13.6 & 56.3 & 27.0 & 22.9 & 10.4 \\
PAR & 8.4 & 43.1 & 12.0 & 8.8 & 7.0 \\
Rn & 19.1 & 71.5 & 30.5 & 20.4 & 10.7 \\
PAR/Rg & 0.62 & 0.76 & 0.44 & 0.38 & 0.67 \\
\hline
\end{tabular}

Table 2. Average air temperature $\left(\mathrm{T},{ }^{\circ} \mathrm{C}\right)$, air relative humidity $(\mathrm{RH}, \%)$, actual vapor pressure $(\mathrm{ea}, \mathrm{kPa})$ and saturation vapor pressure $(\mathrm{es}, \mathrm{kPa})$ of each treatment: $\mathrm{T} 1=$ thermo-reflective screen; $\mathrm{T} 2=$ control; $\mathrm{T} 3=$ red screen; $\mathrm{T} 4=$ blue screen and $\mathrm{T} 5=$ black screen, and outside conditions (temperatura media do ar $\left(\mathrm{T},{ }^{\circ} \mathrm{C}\right)$, umidade relativa do ar (UR, \%), pressão atual de vapor (ea, $\mathrm{kPa})$ e pressão de saturação de vapor (es, $\mathrm{kPa})$ de cada tratamento: $\mathrm{T} 1=$ malha termo-refletora; $\mathrm{T} 2=$ testemunha; $\mathrm{T} 3=$ malha vermelha; $\mathrm{T} 4=$ malha azul; e $\mathrm{T} 5=$ malha preta; e condições a céu aberto). Piracicaba, ESALQ, 2006.

\begin{tabular}{lrrrrrr}
\hline Variables & T1 & \multicolumn{1}{c}{ T2 } & \multicolumn{1}{c}{ T3 } & \multicolumn{1}{c}{ T4 } & \multicolumn{1}{c}{ T5 } & Outside \\
\hline T & 21.80 & 22.40 & 22.70 & 23.30 & 21.80 & 21.50 \\
RH & 79.90 & 80.40 & 81.10 & 80.90 & 81.70 & 85.50 \\
ea & 2.10 & 2.16 & 2.24 & 2.30 & 2.15 & 2.19 \\
es & 2.76 & 2.83 & 2.89 & 2.98 & 2.76 & 2.67 \\
\hline
\end{tabular}

Table 3. Average bromeliads plant height $(\mathrm{cm})$, rosette diameter $(\mathrm{cm})$, leaf length $(\mathrm{cm})$, leaf width $(\mathrm{cm})$ and leaf number per plant in each treatment: $\mathrm{T} 1=$ thermo-reflective screen; $\mathrm{T} 2=$ control; $\mathrm{T} 3=$ red screen; $\mathrm{T} 4=$ blue screen and $\mathrm{T} 5=$ black screen (altura média das bromélias $(\mathrm{cm})$, diâmetro da roseta $(\mathrm{cm})$, comprimento foliar $(\mathrm{cm})$, largura foliar $(\mathrm{cm})$ e número de folhas por planta em cada tratamento: $\mathrm{T} 1=$ malha termo-refletora; $\mathrm{T} 2=$ testemunha; $\mathrm{T} 3=$ malha vermelha; T4= malha azul; e T5= malha preta). Piracicaba, ESALQ, 2006.

\begin{tabular}{llllll}
\hline \multirow{2}{*}{ Treatments } & $\begin{array}{c}\text { Plant } \\
\text { height }\end{array}$ & $\begin{array}{c}\text { Rosette } \\
\text { diameter }\end{array}$ & $\begin{array}{c}\text { Leaf } \\
\text { lenght }\end{array}$ & $\begin{array}{c}\text { Leaf } \\
\text { width }\end{array}$ & \multirow{2}{c}{$\begin{array}{c}\text { Leaf } \\
\text { number }\end{array}$} \\
\cline { 2 - 5 } & \multicolumn{5}{c}{$\mathbf{( c m )}$} \\
\hline T1 & $24.50 \mathrm{ab}$ & $43.83 \mathrm{~b}$ & $38.54 \mathrm{~b}$ & $6.82 \mathrm{ab}$ & $17.17 \mathrm{c}$ \\
$\mathrm{T} 2$ & $23.27 \mathrm{~b}$ & $37.10 \mathrm{c}$ & $28.60 \mathrm{c}$ & $6.65 \mathrm{~b}$ & $18.71 \mathrm{ab}$ \\
$\mathrm{T} 3$ & $27.21 \mathrm{a}$ & $51.65 \mathrm{a}$ & $42.85 \mathrm{a}$ & $7.37 \mathrm{a}$ & $19.54 \mathrm{a}$ \\
$\mathrm{T} 4$ & $24.94 \mathrm{ab}$ & $45.56 \mathrm{~b}$ & $39.06 \mathrm{~b}$ & $7.00 \mathrm{ab}$ & $18.58 \mathrm{ab}$ \\
$\mathrm{T} 5$ & $24.71 \mathrm{ab}$ & $45.25 \mathrm{~b}$ & $40.04 \mathrm{ab}$ & $6.85 \mathrm{ab}$ & $17.75 \mathrm{bc}$ \\
\hline
\end{tabular}

*The averages of the treatments for each biometric parameter followed by same letter do not differ statistically from each other (Tukey, 5\%) [medias dos tratamentos de cada parâmetro biométrico, seguidas de letras iguais não diferem estatisticamente (Tukey, 5\%)].

with the highest Rn average, representing around $31 \%$ of the outside condition. The smallest value was observed again in the black screen (T5), with only $11 \%$, which was a function of it highest solar radiation absorption. Treatments 1 (thermo-reflective screen) and 4 (blue screen) presented intermediate values of transmissivity, around $20 \%$.
Table 2 presents the average values of air temperature (T), relative humidity (RH), actual (ea) and saturation (es) vapor pressures in each one of the treatments, and also outside. In each day evaluated, the air temperature inside the greenhouses was always above $0.3^{\circ} \mathrm{C}$ higher than observed outside. This effect is explained by Guiselini \& 


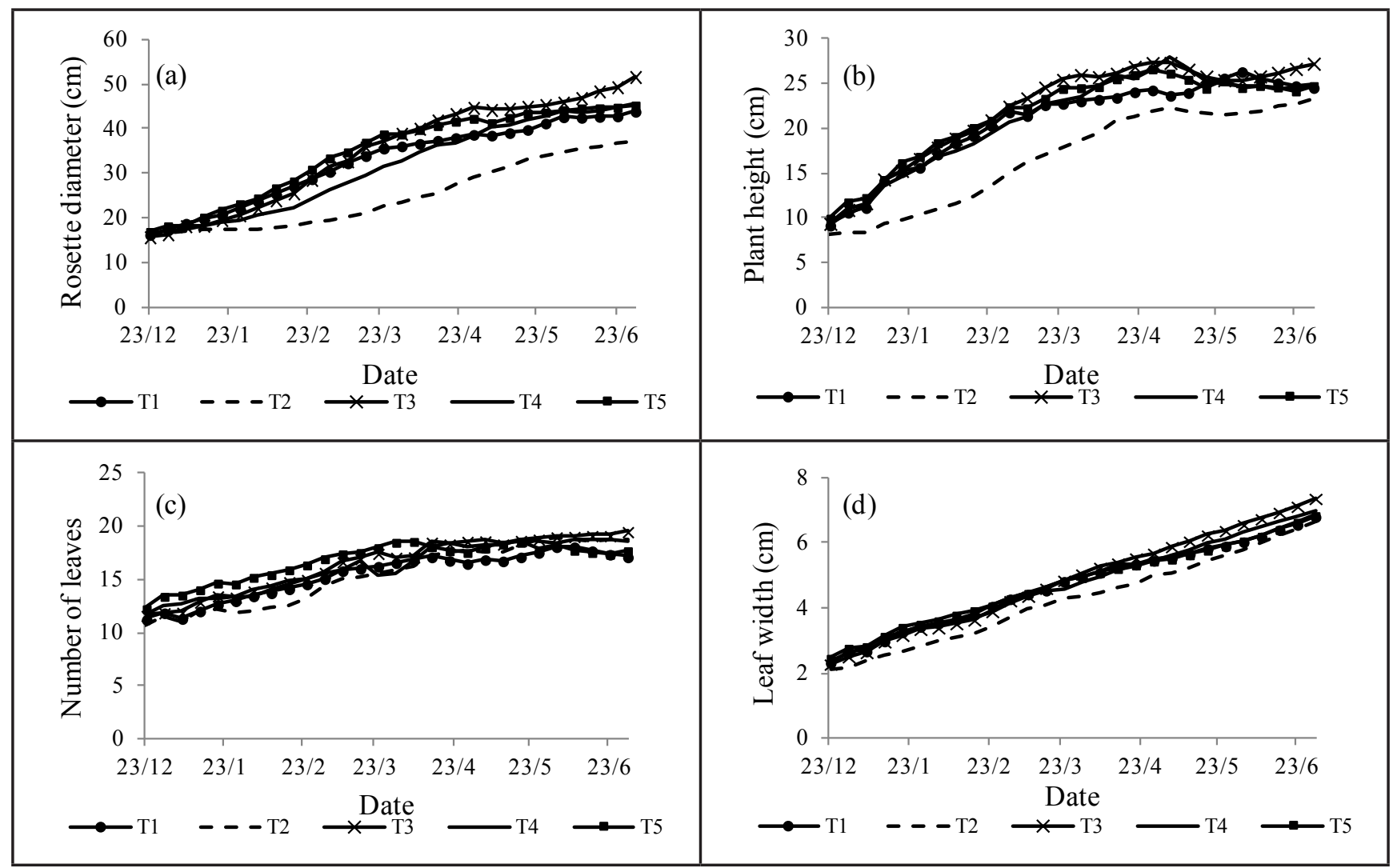

Figure 1. Evolution of bromeliads growth and development parameters: rosette diameter (a); plant height (b); leaf number per plant (c); and leaf width (d), under five different microclimatic conditions: $\mathrm{T} 1=$ thermo-reflective screen; $\mathrm{T} 2=$ control; $\mathrm{T} 3=$ red screen; T4= blue screen and T5= black screen, and outside conditions (parâmetros da evolução do crescimento e desenvolvimento das bromélias: diâmetro da roseta (a); altura da planta (b); número de folhas por planta (c) e largura foliar (d), sob cinco diferentes condições microclimáticas: T1= malha termo-refletora; T2= testemunha; T3= malha vermelha; T4= malha azul; e T5= malha preta). Piracicaba, ESALQ, 2006.

Sentelhas (2004) as a consequence of the partial barrier promoted by the screen to the convection process. However, temperature differences between inside and outside environments were very small, which show the high efficiency of the screens in promoting temperature reduction. Another factor to reduce the thermal differences between the greenhouse and the external conditions is the ventilation promoted by the lateral walls which were constituted of black screen (50\%), allowing the exchange of energy by advection between inside and outside environments.

The similarity of air temperature between $\mathrm{T} 1$ (thermo-reflective screen), T5 (black screen) and outside is related to the use of these screens, since they are responsible for changes in the solar radiation properties, increasing its reflection or absorption, which allows a better temperature control. On the other hand, Abak et al. (1994), evaluating different covering materials in greenhouses, observed that temperature under thermo-reflective screen was higher than under the plastic cover without the screen. The T4 (blue screen) showed to be the covering that promoted the highest temperature, on average, $1.8^{\circ} \mathrm{C}$ higher than outside. The T3 (red screen) presented an intermediate condition, with $0.9^{\circ} \mathrm{C}$ higher than outside.

The variation of $\mathrm{RH}$ inside greenhouse depends on temperature and air circulation. Higher the temperature, lower the RH; more intense the air circulation, lower the RH. Considering that greenhouse temperature was higher than outside, the RH tended to be lower. On average, the T4 (blue screen) presented the highest difference for es and RH among the micro-environments. The other treatments presented very similar RH values among them. When ea was evaluated, the differences were negative indicating that there is more actual water vapor in absolute terms inside the greenhouse. Similar results were reported by Unemoto et al. (2010), who found RH differences between inside and outside conditions of $4.4 \%$.

According to Paula (2001), generally, the bromeliads grow satisfactorily between $15^{\circ}$ and $30^{\circ} \mathrm{C}$, in ventilated locations and with high relative humidity, being recommended to spray water in the leaves, when the temperature is above $35^{\circ} \mathrm{C}$. Based on that, the microclimate conditions obtained in all treatments of this study were within the ideal range for the bromeliads production.

Figure 1 shows the evolution of the biometric parameters on a weekly basis throughout the experimental period. Carvalho et al. (1998) and Laube \& Zotz (2003) proved that there is a direct relationship between solar radiation intensity and bromeliads leaf characteristics. Depending on the intensity of light which reaches the plants, their color, size and format vary. 
For all variables presented in Figure 1, the T2 (without screen cover) was the one that always presented the smallest values in relation to the other treatments, mainly for rosette diameter and plant height. This is mainly related to the fact that bromeliad is a plant sensitive to intense solar radiation, which could inhibit plant growth. Laube \& Zotz (2003) reported that bromeliads plants cultivated under $40 \%$ of shading had their growth and development reduced when compared to those cultivated under $70 \%$ of shading, which is also confirmed here.

Table 3 presents the results of analysis of variance for the average values of plant height, rosette diameter, leaf length, leaf width and leaf number, for each treatment. According to Tukey test, there was significant difference for plant height between treatments T2 (control) and T3 (red screen), because these treatments presented the lowest and the highest plant height, respectively. The same happened to leaf width, with significant difference between $\mathrm{T} 2$ and T3. Rocha (2002), studying different levels of light intensity, obtained a value of leaf width between 7.8 and $8.4 \mathrm{~cm}$ for environments with $80 \%$ of shading.

About the rosette diameter, T1, T4 and T5 were not statistically different, with an average of $44.9 \mathrm{~cm}$. The T3 presented significant difference from other treatments, showing greater diameter compared to them $( \pm 51.6$ $\mathrm{cm})$. This may have occurred by the effect of the red screen on plants etiolation. The leaves were the longest and, consequently, the diameter of the rosette was the largest. T2 presented the smallest diameter, which is related to the growth inhibition caused by the excess of solar radiation. Jasmin et al. (2006), studying the Cryptanthus simosus production with different foliar fertilization and substrates, found plants diameter slightly lower, varying from 28.5 to $30.9 \mathrm{~cm}$, which was also associated to the intensity of solar radiation. However, Rocha (2002) evaluating $A$. fasciata growth under solar radiation level similar to the present study, obtained a rosette diameter averaging $63.2 \mathrm{~cm}$, showing that the correct management of the environment is important to define plant characteristics.

As for the rosette diameter, the smallest value of leaf length occurred in T2 (without screen). In environments with excessive solar radiation, the bromeliads tend to reduce their leaf surface, to prevent high transpiration rates (Carvalho et al., 1998). The greatest values of leaf length were obtained in T3 (red screen) and T5 (black screen). This occurred because, in order to increase the leaf surface and receive greater amount of solar radiation, the bromeliads grown in shaded environments have longer leaves than those grown totally exposed to the sun. The symptoms of the excess of light make the leaves tending to yellow and brown colors, shorter than normal, and with burning leaves. On the other hand, the symptoms of lack of light are soft, fallen and longer leaves, which also make the plants improper for the market.

The red screen (T3) has provided the largest number of leaves, on average 19.6 leaves per plant. The control treatment (T2), despite being the environment with greater availability of light, came in second, with an average of 18.7 leaves per plant, higher than the obtained in the T5 (black screen). According to Rocha (2002), the intensity of the incoming solar radiation directly affects the number of leaves in the bromeliad $A$. fasciata. In such study, plants grown under black screen of $18-40 \%$ of shading showed a number of leaves $35 \%$ greater compared to plants grown under black screen of $60-80 \%$ of shading. It means that adequate levels of light are essential for the full development of the leaves.

The leaf number of T1 (thermoreflective screen) was lower than the values obtained in T2, T3 and T4; but it was similar to the value obtained on the black screen (T5), normally used for the flowers production before the advent of thermo-reflective screens. According to Shahak (2008), black shading screen reduces the amount of light transmitted to the plants, but it does not affect the quality of the light, which means that the spectral composition remains the same. In this study it was possible to confirm this by the relationship PAR/ Qg of the T1, which was very similar to that obtained for T5 (Table 1).

Based on the obtained results, we can conclude that: as the number of leaves of T1 (thermo-reflective screen) was similar to the value obtained under the black screen (T5), the replacement of black screen by thermo-reflective will not result in significant changes for $A$. fasciata bromeliad growth in greenhouses; the higher differences between the evaluated treatments occurred for the variables rosette diameter and leaf length; higher values for all biometric variables of $A$. fasciata bromeliad were obtained when it was cultivated under the red screen (T3), showing that this screen is a possible alternative for growers interested in obtaining more vigorous plants. It is important to emphasize that all the results exposed in this study may differ among seasons and distinct climates, mainly in temperate ones.

\section{ACKNOWLEDGEMENTS}

The first author is thankful to FAPESP for the scholarship for developing this study. The second author is a Research Scientist of CNPq, with a productivity fellowship, level 2.

\section{REFERENCES}

ABAK K; BASÇETINÇELIK A; BAYTORUN Ö. 1994. Influence of double plastic cover and the thermal screens on greenhouse temperature, yield and quality of tomato. Acta Horticulturae 366: 149-154.

AL-HELAL IM; ABDEL-GHANY AM. 2010. Responses of plastic shading nets to global and diffuse PAR transfer: Optical properties and evaluation. NJAS - Wageningen Journal of Life Sciences 57: 125-132.

BRIASSOULIS D; MISTRIOTIS A; ELEFTHERAKIS D. 2007. Mechanical behaviour and properties of agricultural nets - Part I: Testing methods for agricultural nets. Science Direct 26: 822-832.

CARVALHO LC; ALMEIDADR; ROCHA CFD. 1998. Phenotypic response of Neoregelia johannis (Bromeliaceae) dependent on light intensity reaching the plant microhabitat. Selbyana 19: 240-244.

CARVALHO LC; ROCHA CFD. 1999. Forma da bromélia depende da luz. Ciência Hoje 26: 72-74.

CERMEÑO ZS. 1994. Construccion de invernaderos. Madrid: Mundi-Prensa, 445p.

GRANT JR; ZIJLSTRA G. 1998. An annotated catalogue of the generic names of the 
Bromeliaceae. Selbyana 19: 92-121.

GUISELINI C; SENTELHAS PC. 2004. Use of shading screens in greenhouses I: effect on temperature and relative humidity. Revista Brasileira de Agrometeorologia 12: 9-17.

JASMIN JM; TOLEDO RRV; CARNEIRO LA; MANSUR E. 2006. Coconut fiber and foliar fertilization in the Crypthathus sinuosus growing and nutrition. Horticultura Brasileira 24: 309-314

JEONG KY; PASIAN CC; MCMAHONC M; TAY D. 2009. Growth of six Begonia species under shading. The Open Horticulture Journal 2: 22-28.

JOHANSSON D. 1974. Ecology of vascular epiphytes in West African rain forest. Acta Phytogeographica Suecica 59: 1-136.

LAUBE S; ZOTZ G. 2003. Which abiotic factors limit vegetative growth in a vascular epiphyte? Functional Ecology 17: 598-604.

LUGASSI-BEN-HAMO M; KITRON M; BUSTAN A; ZACCAI M. 2010. Effect of shade regime on flower development, yield and quality in Lisianthus. Scientia Horticulturae 124: 248-253.

MASHONJOWA E; RONSSE F; MHIZHA T; MILFORD JR; LEMEUR R; PIETERS JG. 2010. The effects of whitening and dust accumulation on the microclimate and canopy behaviour of rose plants (Rosa hybrida) in a greenhouse in Zimbabwe. Solar Energy 84: 10-23.

MEDEIROS HM. 2002. Desempenho de métodos de manejo de irrigação para a cultura do tomateiro cultivado em campo e em casa de vegetação. Viçosa: UFV. 100p (Dissertação mestrado).

NOMURA ES; LIMA JD; RODRIGUES DS; GARCIA VA; FUZITANI EJ; SILVA SHM. 2009. Growing and production of anturio cultivated under different shading screens. Ciência Rural 39: 1394-1400.

OLIVEIRA MRV. 1995. The use of greenhouses in Brazil: advantages and disadvantages. Pesquisa Agropecuária Brasileira 30: 10491060.

OREN-SHAMIR M; GUSSAKOVSKY EE; SHPIEGEL E; NISSIM-LEVI A; RATNER K; OVADIA R; GILLER Y; SHAHAK Y. 2001. Coloured shade nets can improve the yield and quality of green decorative branches of Pittosphorum variegatum. J. Hort. Sci. Biotech. 76: 353-361.

PANDORFI CG. 2006. Manejo de cobertura de ambientes protegidos: alterações micrometeorológicas e efeitos na produção e na qualidade de gérbera. Piracicaba: USPESALQ. 95 p (Tese doutorado).

PAULA CC. 2001. Practical guide for bromeliads cultivation. UFV, 73p.

PITTENDRIGH CS. 1948. The BromeliadAnopheles-Malaria complex in Trinidad. I - The bromeliad flora. Evolution 2: 58-89.

ROCHA PK. 2002. Bromeliads development in greenhouses with screens at different heights and shading levels. Piracicaba: USP-ESALQ. 84 p (Dissertação mestrado).

SENTELHAS PC; SANTOS AO. 1995. Greenhouses: microclimatic aspects. Revista Brasileira de Horticultura Ornamental 1: 108-115.

SHAHAK Y. 2008. Photo-selective netting for improved performance of horticultural crops - A review of ornamental and vegetable studies carried out in Israel. Acta Horticulturae 770: 161-168.

UNEMOTO LK; FARIA RT; ASSIS AM; DESTRO D. 2010. The vegetative development of Sinningia leucotricha Hoehne (Moore) under different levels of shading. Brazilian Archives of Biological Technology 53: 47-53.

WENT FW. 1940. Soziologie der Epiphyten eines tropischen Regenwalde. Ann. Jardin Botanique de Buitenzorg 50: 1-98. 